\title{
MODERN STRUCTURAL-DYNAMIC ORGANISATION OF PHYTOCOENOSES AT POST-AGRICULTURAL LANDSCAPES IN SOUTH-WESTERN TRANS-BAIKAL (ILLUSTRATED BY KEY SITES, THE SELENGA RIVER BASIN)
}

\author{
Alexander Sizykh ${ }^{1 *}$, Alexey Shekhovtsov ${ }^{2}$, Alexander Gritsenyuk ${ }^{3}$ \\ ${ }^{1 *}$ Siberian Institute of Plants Physiology and Biochemistry of RAS SB, Russia, Irkutsk; \\ ${ }^{2} V . B$. Sochava Institute of Geography of RAS SB, Russia, Irkutsk; \\ ${ }^{3}$ V.R. Filippov Buryat State Academy of Agriculture, Russia, Ulan-Ude;
}

*Corresponding author Alexander Sizykh, e-mail: alexander.sizykh@gmail.com;

Received January 2020; Accepted February 2020; Published March 2020;

DOI: https://doi.org/10.31407/ijees10.203

\begin{abstract}
Studies of the peculiarities of vegetation structure on post-agricultural landscapes in central part of the Selenga R. basin (South-Western Trans-Baikal) revealed modern trends of phytocoenoses formation during last decades since the land stopped being used for cereals agriculture and pasturage. We have to state while characterizing the peculiarities of vegetation transformation in the Selenga R. Basin that land use in this region under the conditions of relatively drought periods during different years resulted in evident elevated anthropogenic degradation of soil and vegetation cover. As the Selenga R. Basin is situated within very important biogeographic boundaries, namely within boundaries between regions and provinces of southern boreal forests and zonal dry bunchgrass steppes of Central Asian type, where zonal forest-steppe is formed with its transition into zonal steppe, the processes of environment decay are better expressed.
\end{abstract}

Keywords: vegetation structure, post-agricultural landscapes, biogeographic boundaries, zonal steppe and foreststeppe, basin of Selenga river, Trans-Baikal. 